\title{
Physico-chemicals and sensory quality of Peaches treated with hot water during the cold storage
}

\author{
Abdul Sattar Shah ${ }^{1,2^{*}}$, Said Wahab ${ }^{1}$, Sumayya Rani ${ }^{2}$, Ziaur Rahman ${ }^{2}$, \\ Inayat-ur-Rahman ${ }^{2}$, Abdul Basir2 ${ }^{2}$, Malik Muhammad Hashim³, \\ Muhammad Faisal Anwar Malik ${ }^{2}$ and Syed Abdul Majeed Shah ${ }^{2}$ \\ 1. Department of Food Science and Technology, The University of Agriculture Peshawar-Pakistan \\ 2. Department of Agriculture, The University of Swabi, Anbar Swabi-Pakistan \\ 3. Department of Food Science and Technology, Faculty of Agriculture, Gomal University, D.I. Khan-Pakistan \\ *Corresponding author's email: shahjee15@ gmail.com; shahjee515@yahoo.com \\ Citation \\ Abdul Sattar Shah, Said Wahab, Sumayya Rani, Ziaur Rahman, Inayat-ur-Rahman Malik, Abdul Basir, Malik \\ Muhammad Hashim, Faisal Anwar Malik and Syed Abdul Majeed Shah. Physico-chemicals and sensory \\ quality of Peaches treated with hot water during the cold storage. Pure and Applied Biology. Vol. 5, Issue 4, \\ pp1245-1253. http://dx.doi.org/10.19045/bspab.2016.50149
}

\begin{tabular}{llll}
\hline Received: 16/08/2016 & Revised: 28/10/2016 & Accepted: 04/11/2016 & Online First: 09/11/2016 \\
\hline
\end{tabular}

\section{Abstract}

The objectives of this study were to investigate and compare the effects of hot water treatments on the physico-chemical and sensory quality of peach fruit during cold storage. Peach fruit were harvested at physiological mature stage and were treated with hot water at $35^{\circ} \mathrm{C}, 40^{\circ} \mathrm{C}, 45^{\circ} \mathrm{C}, 50^{\circ} \mathrm{C}$, $55^{\circ} \mathrm{C}, 60^{\circ} \mathrm{C}$ and control with tap water $\left(20^{\circ} \mathrm{C}\right)$ for 2 minutes to evaluate the effects of hot water. Peach fruit were stored at $0^{\circ} \mathrm{C} \pm 1{ }^{\circ} \mathrm{C}$ with $90 \% \pm 5 \% \mathrm{RH}$ for 30 days during the period of analysis. Hot water treatments have significant effect on moisture loss, TSS, pH, acidity, sugar acid ratio, reducing sugar, non-reducing sugar, vitamin $\mathrm{C}$, firmness and organoleptic evaluation of peaches. There was no significant effect of these treatments on the ash content of fruits. Hot water treatment at $50^{\circ} \mathrm{C}$ for $2 \mathrm{~min}$ reduced moisture loss and delay in the increase of TSS, $\mathrm{pH}$, sugar acid ratio, reducing sugar, and decrease in acidity, non-reducing sugar, vitamin $\mathrm{C}$ and firmness. Overall, the results indicate that hot water treatment at $50^{\circ} \mathrm{C}$ has tremendous potential for maintaining physicochemical and sensory quality of peach during cold storage.

Keywords: Hot water treatment; Peaches; Physico chemicals and sensory attribute; Storage life

\section{Introduction}

Peach [1] is climacteric fruit and is one of the most important stone fruit grown in temperate zones of the world. Peaches contain high amount of vitamins, minerals, carotenoids, phenolic compounds (catechin, neochlorogenic acid, chlorogenic acid, caffeic acid), and anti-oxidant which are very important for human health [2]. Besides
Northern areas peach is also grown in Peshawar region, Swat, South Wazeristan Hazara and Malakad division [3]. Postharvest losses in peaches is very high due to its perishable nature and lack of post-harvest techniques. Round about 50\% losses occur from production to the consumption [2]. Due to very high perishable nature, the postharvest life of fresh peach is very short 
and is a main hurdle in supplying the fruit to national and international markets [4].

Numerous techniques, including physical (such as heat and UV-C pretreatments, modified atmosphere packaging,) and chemical methods (such as Calcium chloride, salicylic acid, methyl jasmonate (MJ)) and $1 \mathrm{MCP}$ ), have been applied to peach fruit to control post-harvest losses that occurs during low temperature storage $[5,6]$. [7] reported that hot water treatment is most effective techniques to reduce the post-harvest losses of fruits. Hot water treatments delay ripening and respiration processes and increase the storage life of fruits $[8,9]$.

Keeping the above facts in view present research was conducted to study the effect of post-harvest hot water treatments on physicochemical and sensory attribute of peach fruits during the storage.

\section{Materials and methods}

This research work was conducted in Food Technology Section, Agricultural Research Institute Tarnab, Peshawar. The late maturing variety Indian Blood "Swat No. 8" was selected for the research.

\section{Preparation of sample}

Peach fruits of homogeneous size and color were divided into different lots for various treatments. The fruits were stored at $0^{\circ} \mathrm{C}$ $\pm 1{ }^{\circ} \mathrm{C}$ with $90 \% \pm 5 \% \mathrm{RH}$ during the period of analysis. The data regarding various parameters were recorded at 10 days interval i.e. $0,10,20$ and 30 days and so on until $50 \%$ of fruit samples were spoiled.

\section{Experimental plan}

Peaches were treated with hot water for three minutes. Hot water treatments were applied as follows:

$\mathrm{T}_{0}=$ peaches with no treatment (control)

$\mathrm{T}_{1}=$ peaches with hot water treatment at $35^{\circ} \mathrm{C}$ $\mathrm{T}_{2}=$ peaches with hot water treatment at $40^{\circ} \mathrm{C}$ $\mathrm{T}_{3}=$ peaches with hot water treatment at $45^{\circ} \mathrm{C}$
$\mathrm{T}_{4}=$ peaches with hot water treatment at $50^{\circ} \mathrm{C}$ $\mathrm{T}_{5}=$ peaches with hot water treatment at $55^{\circ} \mathrm{C}$ $\mathrm{T}_{6}=$ peaches with hot water treatment at $60^{\circ} \mathrm{C}$ Moisture content of peach fruit was determined using the standard method AOAC (2000). The TSS, pH, acidity, sugar acid ratio, reducing sugar, non-reducing sugar, ash, and vitamin $\mathrm{C}$ content of peach samples were determined by standard method of AOAC (2000).

Fruit firmness was observed on two pared sides of 5 fruits from each replicate using a penetrometer (Wagner Fruit Firmness Tester model FT-327) [10]. Sensory evaluation was carried out by 9 point hedonic scale as described by [11].

\section{Statistical analysis}

The data were analyzed statistically by using completely randomized design, and means were separated by applying LSD test as illustrated by [12]. Analysis of variance (ANOVA) was performed on the results for every variable to measure the significance of the effects of temperature and storage period. Means were separated by the LSD test at $\mathrm{P}<0.05$ level using Software (2006) Statistix Version 8.1.

\section{Result and discussions Moisture content/ Water loss}

A significant variation of moisture content was observed in all the treatments (Figure 1). Both the treatments and storage intervals have significant effects on the moisture content. Maximum percent decline in moisture content was found in control (7.12\%) followed by $\mathrm{T}_{2}$ while minimum percent decrease in moisture was observed in $\mathrm{T}_{4}(2.17 \%)$ followed by $\mathrm{T}_{5}$ after 30 days of storage. The moisture loss might be due to metabolic activities, transpiration and respiration process in fruits. A decrease of the moisture losses was observed in hot water treated fruits. Our findings are in confirmation with previous work of $[13,2]$. 


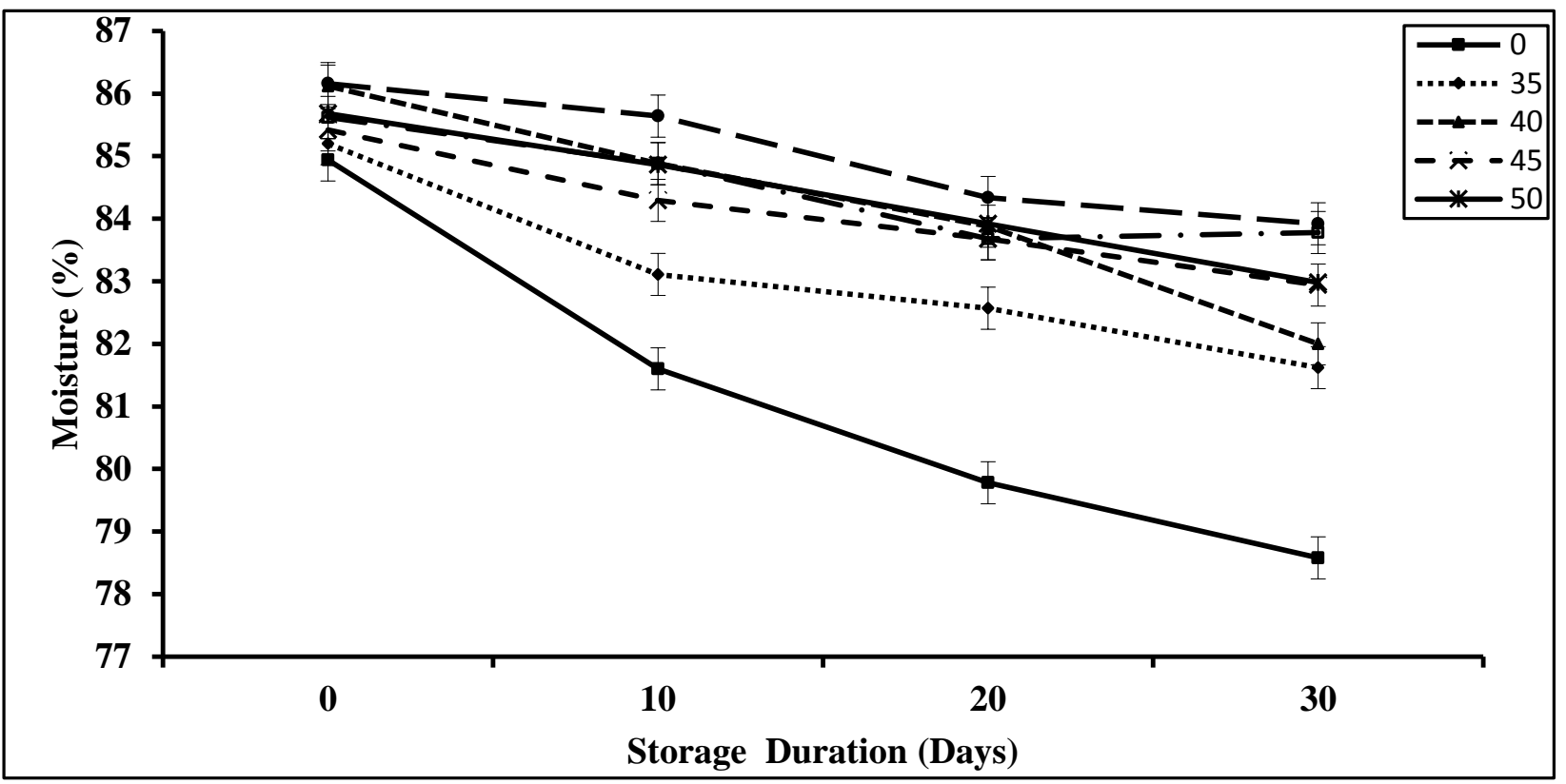

Figure 1. Effect of hot water treatment and storage intervals on the moisture content (\%) of peach fruits.

Total soluble solid content

In all treatments total soluble solid content slightly increased during the 30 days of storage intervals (Figure 2). In hot water treated samples slow increase of TSS was observed as compare to control. Similar observations have also been reported by [14, 3]. This slow increase of TSS in treated samples might be due to slow down the ripening process and inactivation of enzyme.

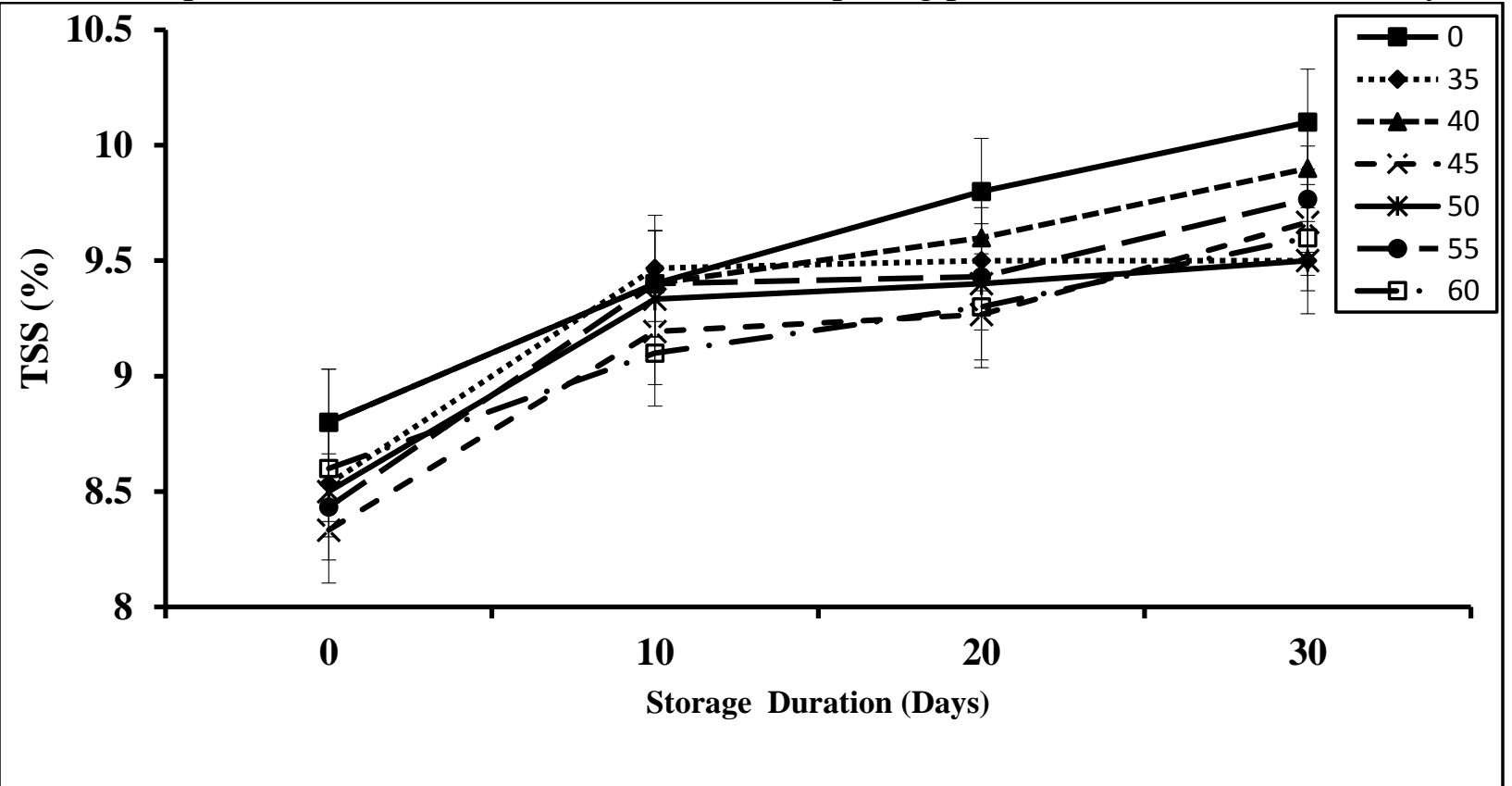

Figure 2. Effect of hot water treatment and storage intervals on the TSS ( $\left.{ }^{0} \mathrm{Brix}\right)$ of peach fruits 


\section{Titratable acidity}

The treatments have a non-significant effect on the titratable acidity (Figure 3). But storage interval have significant effect on acidity. These results are in agreement with the findings of $[14,2,3]$ who also observed that hot water treatment had no significant effect on titratable acidity in peaches and nectarines. The decrease in acid contents might be due to ripening and respiration process.

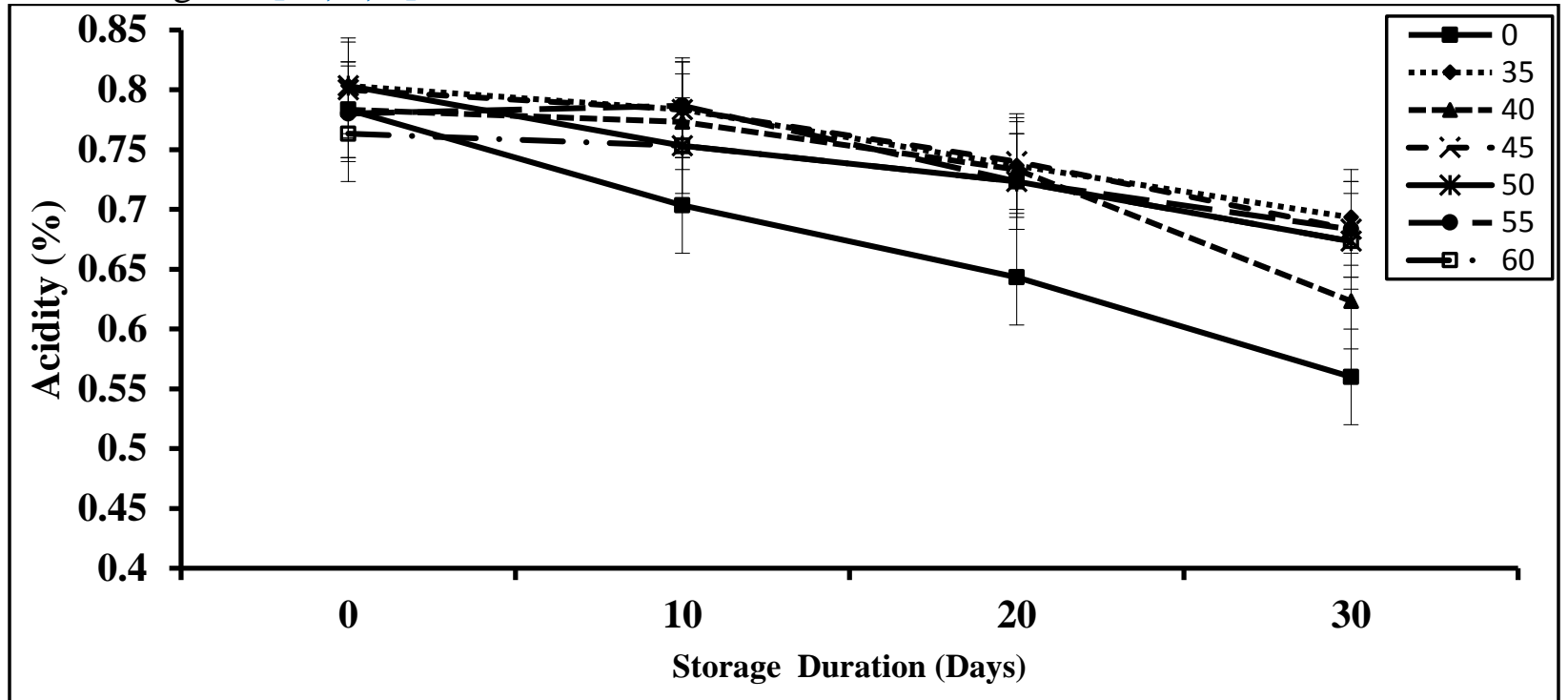

Figure 3. Effect of hot water treatment and storage intervals on the acidity (\%) of peach fruits

\section{pH}

A non-significant difference of $\mathrm{pH}$ content was observed in hot water treated samples along with control (Figure 4). However, the effect of storage intervals was significant. A gradual increase in $\mathrm{pH}$ was recorded with

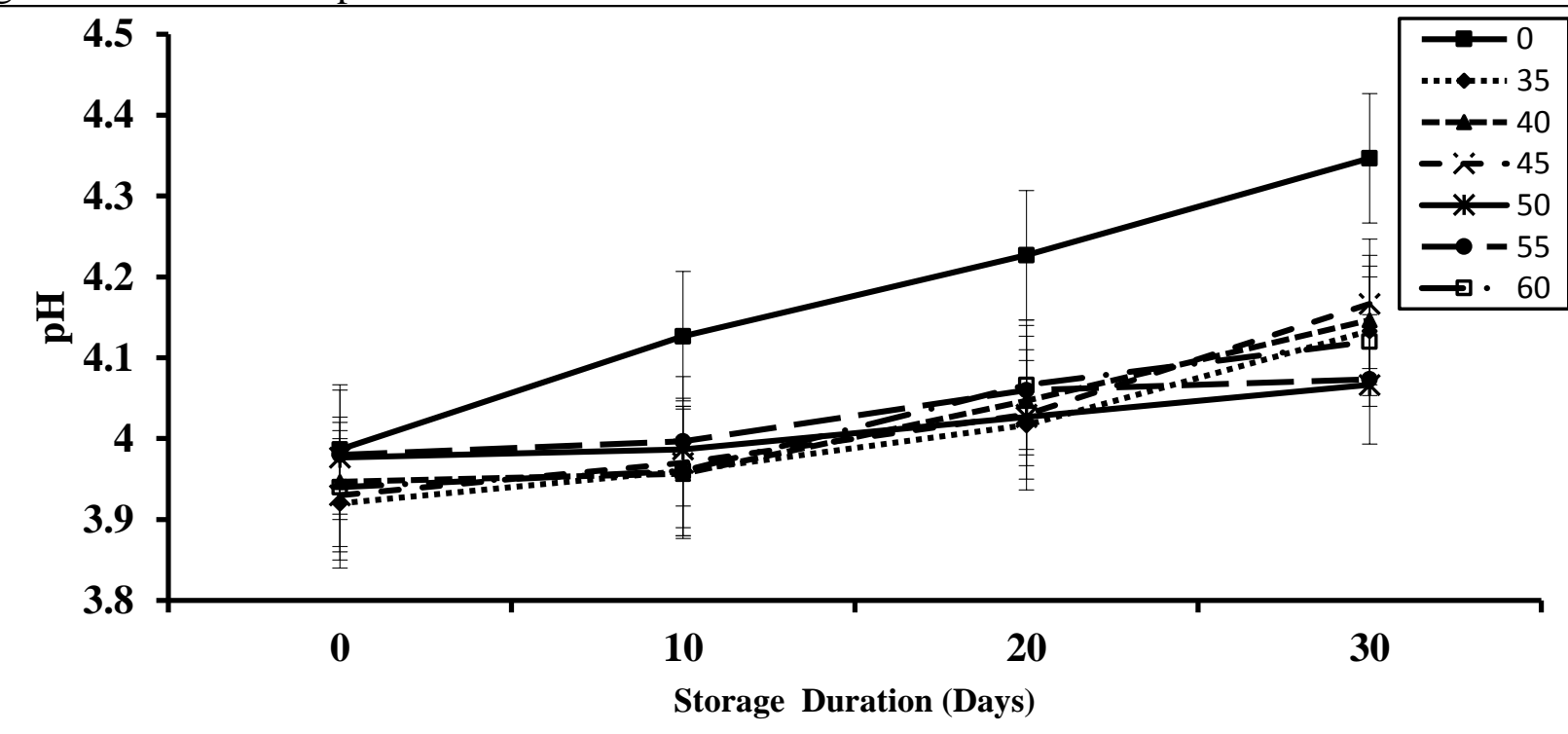

Figure 4. Effect of hot water treatment and storage intervals on the $\mathrm{pH}$ of peach fruit 


\section{Sugar acid ratio}

A significant increase in sugar acid ratio was found during storage (Figure 5). Maximum mean sugar acid ratio (14.69) was noticed in $\mathrm{T}_{0}$ followed by $\mathrm{T}_{2}$; whereas minimum was found in $\mathrm{T}_{4}$. The sugar acid ratio increase from 10.95 on 0 -day to 15.42 on 30 -days. The increase in sugar acid ration might be due to increase in simple sugars concentration. Similar observations have also been reported by $[14,2,15]$.

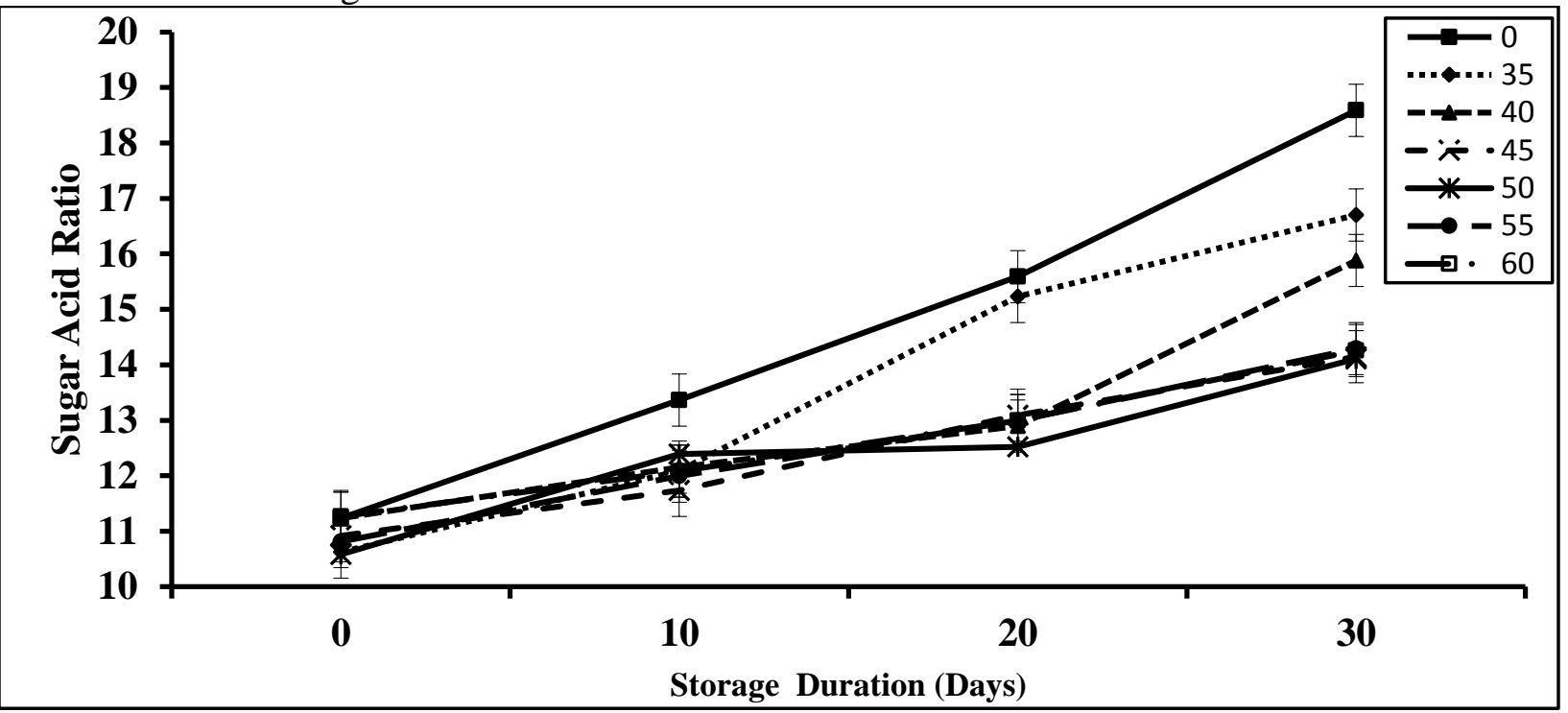

Figure 5. Effect of hot water treatment and storage intervals on the sugar acid ratio of peach fruits

\section{Reducing sugar $(\%)$}

Both the treatments and storage intervals have significant effect on the reducing sugar (Figure 6). Maximum mean value (2.11) was recorded in $\mathrm{T}_{0}$ followed by $\mathrm{T}_{2}$ and minimum in $\mathrm{T}_{6}$. The reducing sugar content increased significantly with the increase of storage

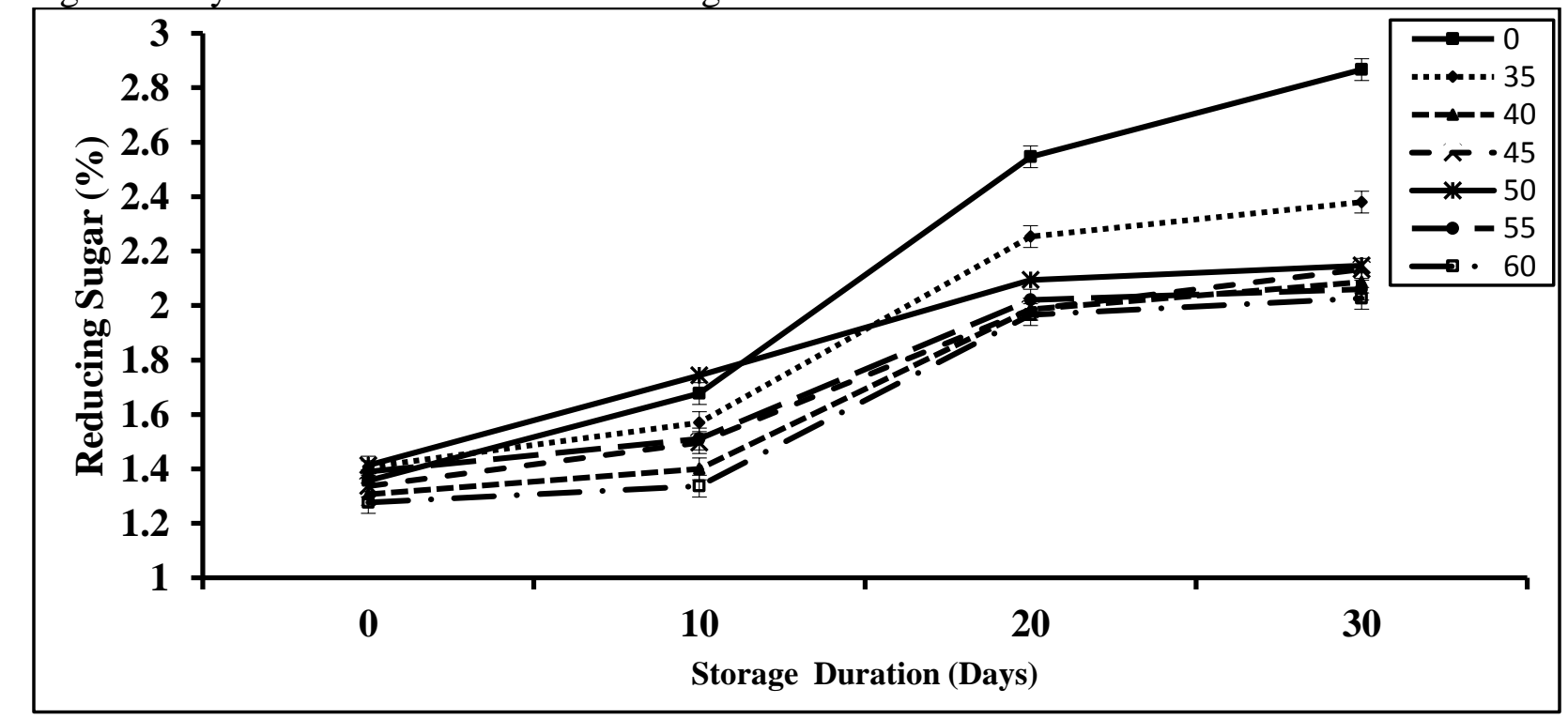

Figure 6. Effect of hot water treatment and storage intervals on the reducing sugar (\%) of

peach fruit period. The value of 1.35 was obtained on 0 day which increased to 2.24 at the end of storage period. The result is also in accordance with the reports of $[16,17]$ who also observed the similar trend of reducing sugar in peaches. 
Non-reducing sugar (\%)

Both the treatments and storage intervals have significant effect on the non-reducing sugar (Figure 7). Maximum mean value (5.45) was recorded in $T_{0}$ followed by $T_{3}$ and minimum in $\mathrm{T}_{0}$. The reducing sugar content decreased significantly with the increase of storage period. The value of 5.60 was obtained on 0-day which increased to 5.01 at the end of storage period. The result is also in accordance with the reports of [16, 17] who also observed the similar trend of non-reducing sugar in peaches.

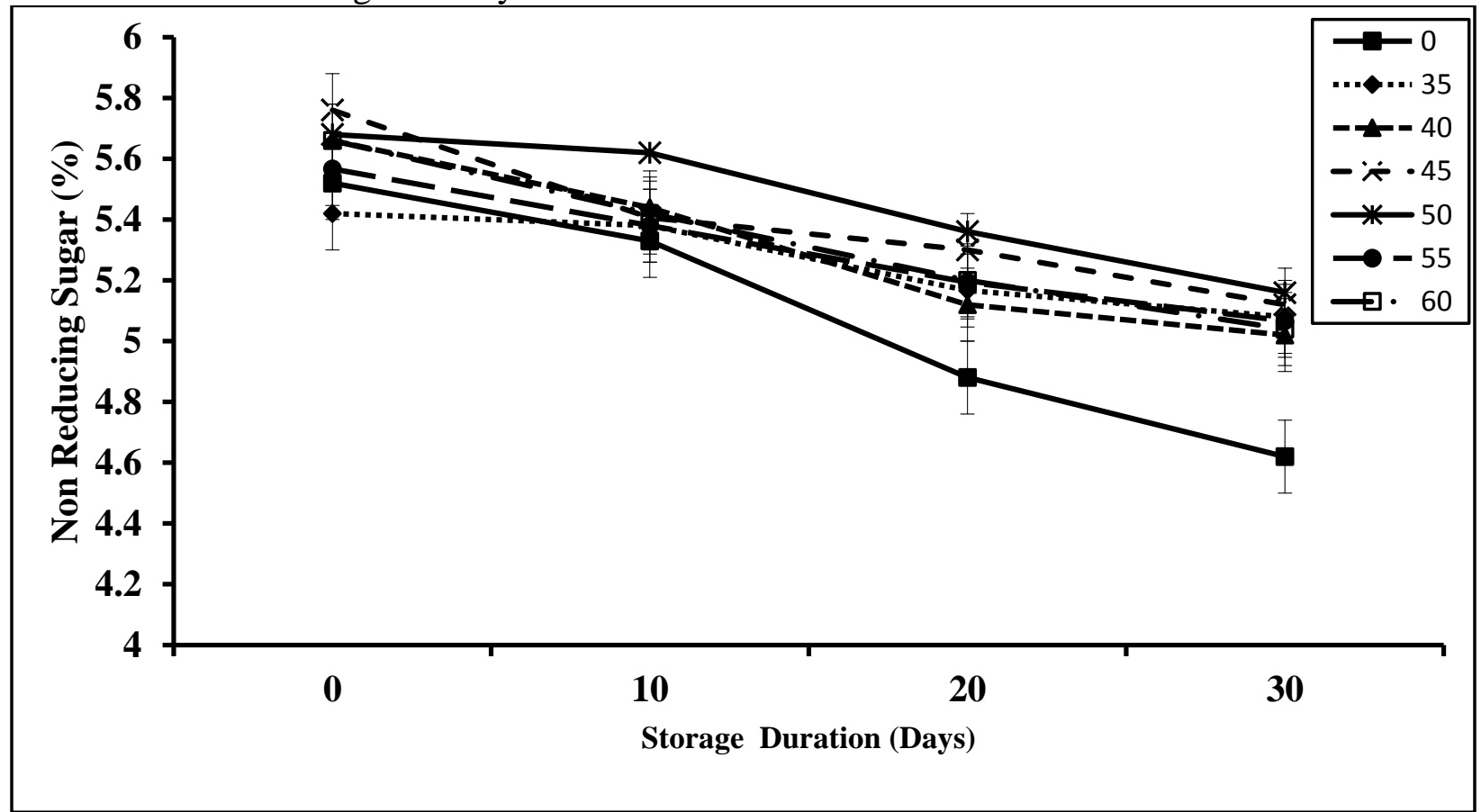

Figure 7. Effect of hot water treatment and storage intervals on the non-reducing sugar (\%) of peach fruits

\section{Ascorbic acid}

A significant decrease of ascorbic acid was evaluated in all the samples. The data showed that highest ascorbic acid (8.25) was observed in $\mathrm{T}_{4}$ followed by $\mathrm{T}_{3}$ while minimum (7.34) was noted in To. Similarly, ascorbic acid was maximum (9.6) at day zero to (6.27) with a continuous loss up to 30 days storage. These results are in agreement with the findings of $[14,3]$ who found that hot water treatment reduce the ascorbic acid losses during storage of peaches.

\section{Ash (\%)}

Both the treatments and storage intervals have non-significant effect on the ash (\%) content of peaches.
Fruit flesh firmness $\left(\mathrm{kg} / \mathrm{cm}^{2}\right)$

Fruit flesh firmness significantly decreased during 30 days of storage at $0^{\circ} \mathrm{C}$ in all the treatments (Figure 9). Maximum mean score for flesh firmness (6.28) was noticed in $\mathrm{T}_{3}$ followed by $\mathrm{T}_{4}$; whereas minimum was found in $T_{0}$. A significant decline in peach flesh firmness was observed during storage. The flesh firmness decreased from 6.46 on 0 -day to 5.52on 30-days. Decrease in fruit flesh firmness might be due to the enzymatic activities on the cell wall or might be due to respiration. These results are in agreement with the findings of $[14,17]$ who also observed that fruits treated with $50^{\circ} \mathrm{C}$ of hot water were firmer than untreated fruits. 


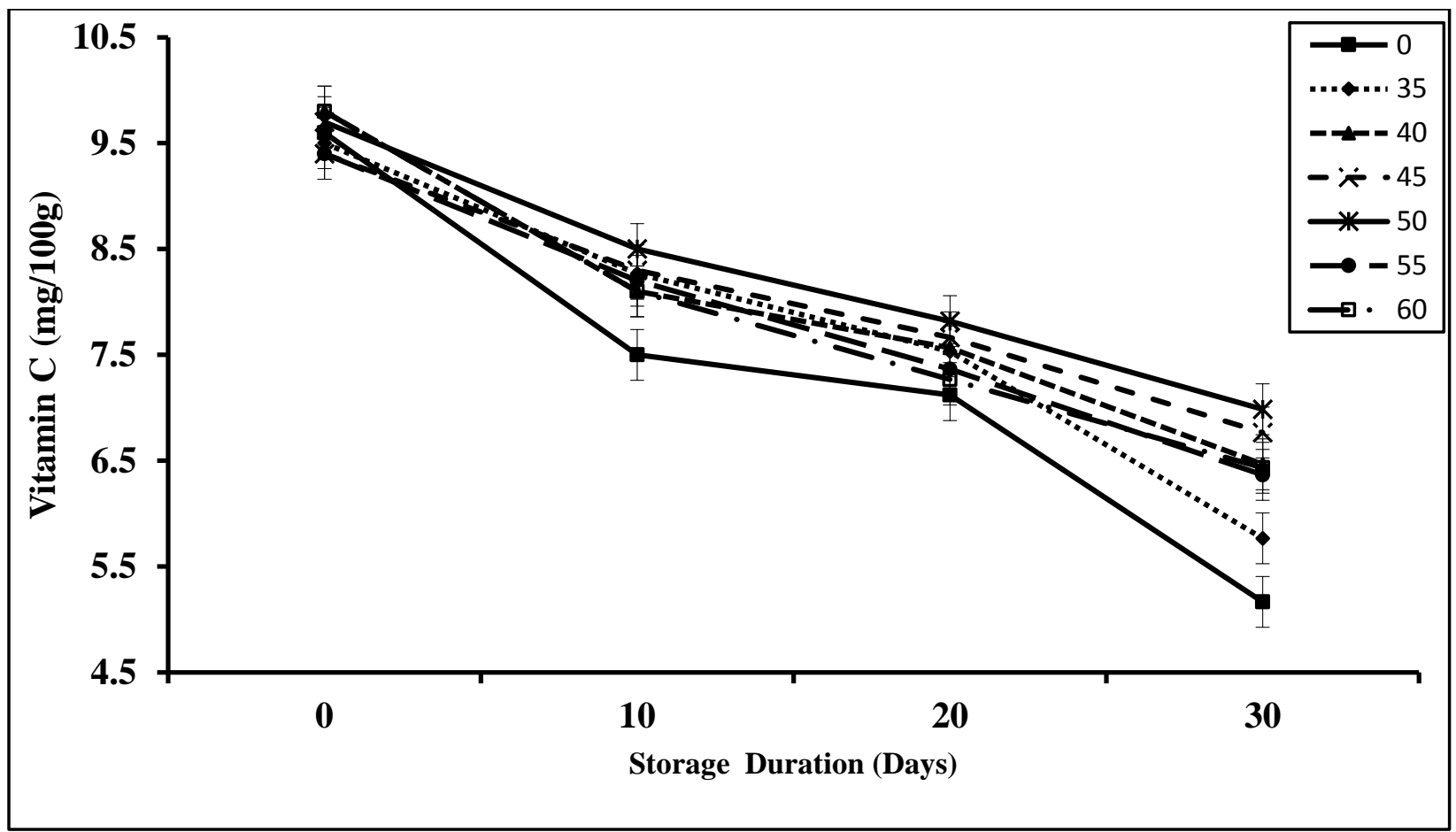

Figure 8. Effect of hot water treatment and storage intervals on vitamin $\mathrm{C}(\mathrm{mg} / \mathrm{100g}) \mathrm{of}$ peach fruits

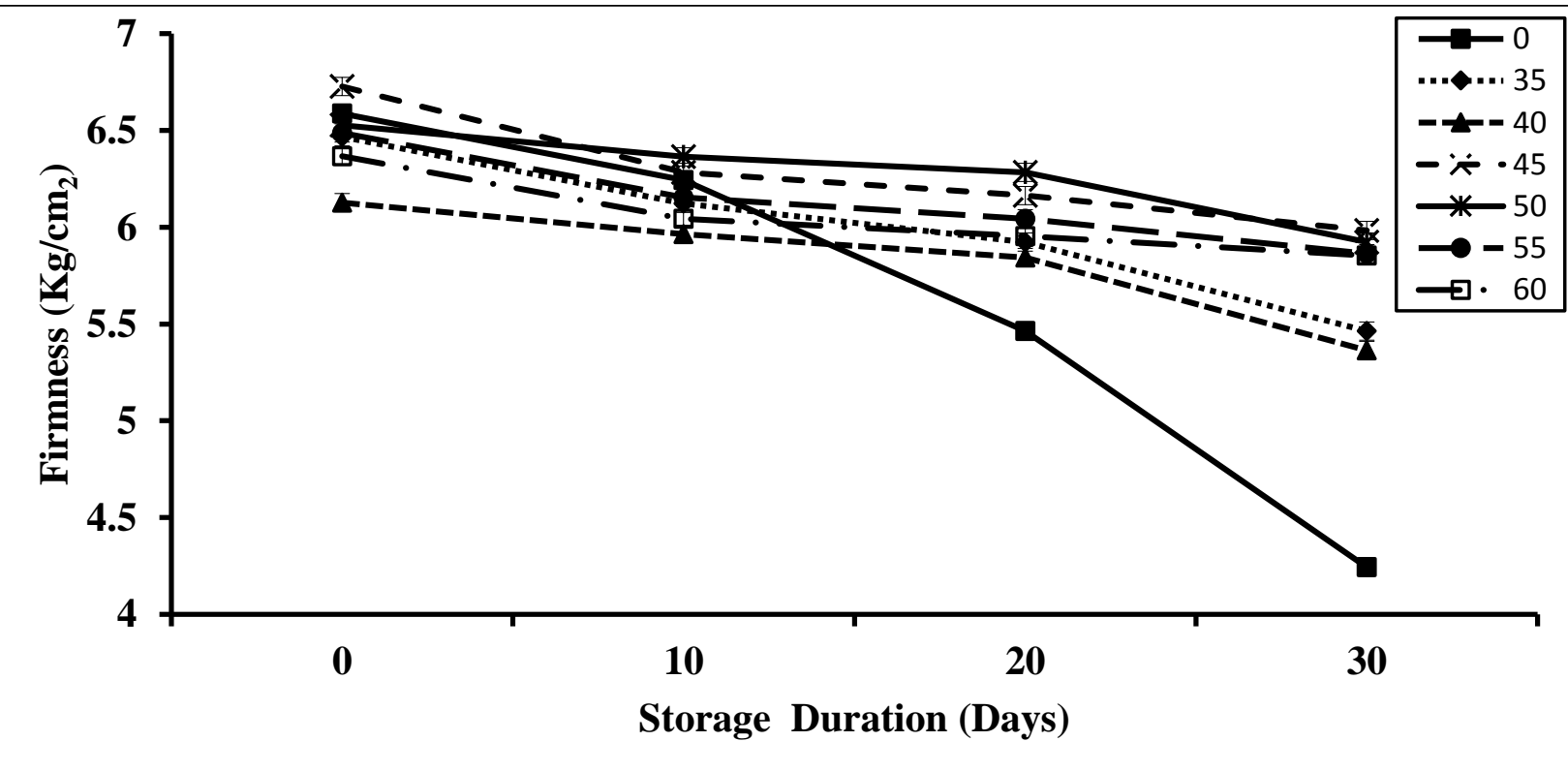

Figure 9. Effect of hot water treatment and storage intervals on firmness $\left(\mathrm{Kg} / \mathrm{cm}_{2}\right)$ of peach fruits

\section{Sensory evaluation}

For sensory evaluation, fruits were analysed through colour, flavour, texture, juiciness and over all acceptability (Figure 10). A significant variation for over all acceptability was found in all the treatments. Maximum mean score for overall acceptability (6.7) was noticed in $\mathrm{T}_{4}$ followed by $\mathrm{T}_{3}$; whereas minimum was found in $\mathrm{T}_{0}$. A significant decline in overall 
acceptability score was observed during storage. The overall acceptability score was decreased from (6.69) at day zero to (5.83) up to 30 days storage. These results are in

agreement with the findings of $[3,2]$ that hot water treated fruits at $50{ }^{0} \mathrm{C}$ have maximum score for overall acceptability as compare to control and other treated fruits.

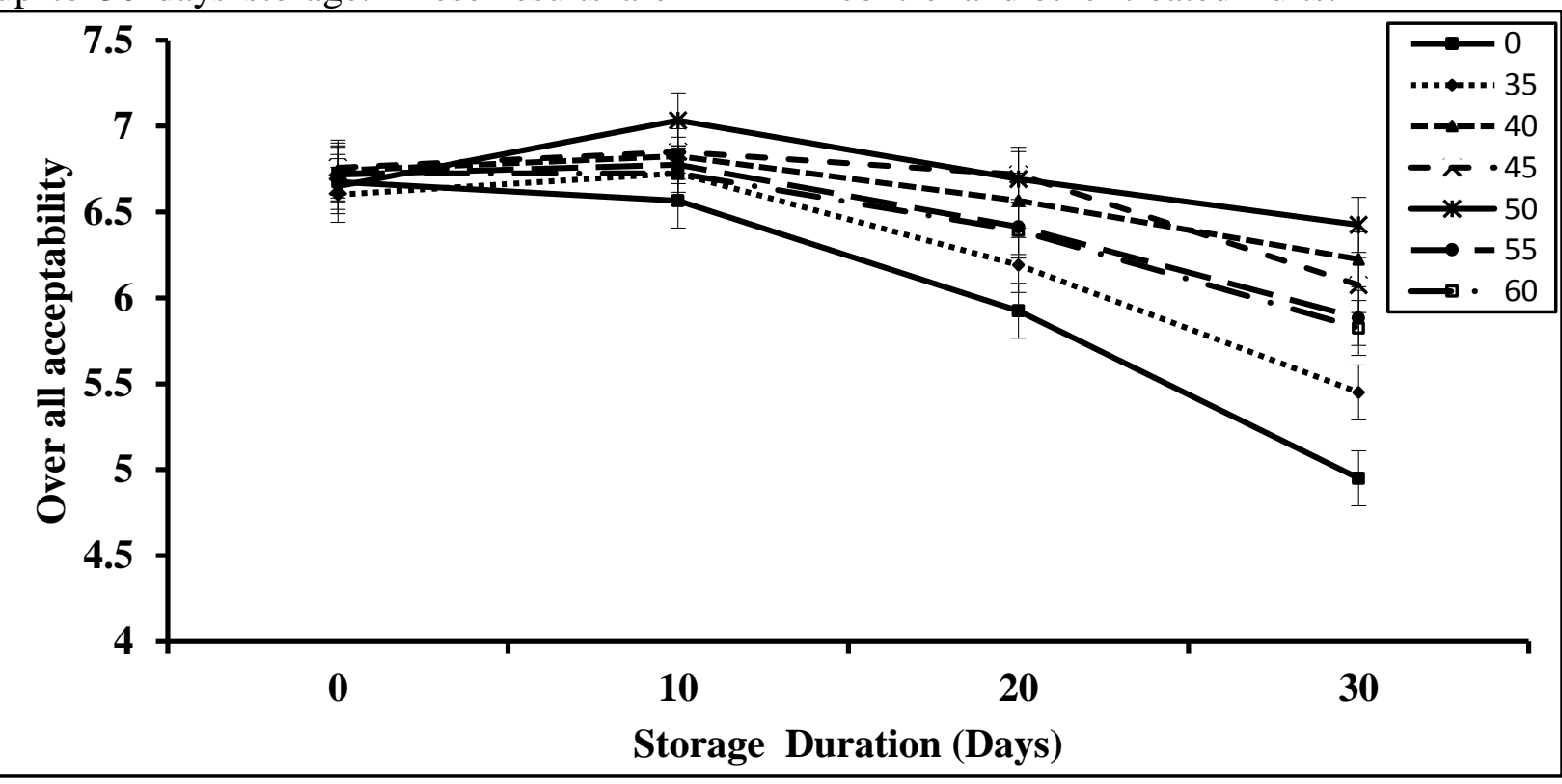

Figure 10. Effect of hot water treatment and storage intervals on overall acceptability of peach fruits

\section{Conclusion}

The aim of this research was to evaluate effects of hot water treatment on physicochemicals and sensory quality of peaches. Hot water treatment at $50^{\circ} \mathrm{C}\left(\mathrm{T}_{4}\right)$ were found most effective in maintaining peach fruit quality in terms moisture loss, TSS, $\mathrm{pH}$, acidity, sugar acid ratio, reducing sugar, nonreducing sugar, vitamin $\mathrm{C}$, firmness and sensory evaluation.

\section{Authors' contributions}

Conceived and designed the experiments: AS Shah \& $S$ Wahab Performed the experiments: AS Shah, S Rani, Z Rahman, IURahman, A Basir \& SAM Shah, Analyzed the data: AS Shah, MM Hashim \& MFA Malik, Contributed reagents/ materials/ analysis tools: AS Shah, S Wahab, MM Hashim, MFA Malik, Wrote the paper: AS Shah, MM Hashim \& MFA Malik.

\section{Acknowledgments}

The principal author is grateful ARI, Tarnab and NIFA Peshawar for providing research facilities. I am very thankful to The University of Agriculture Peshawar, Pakistan for technical support and also especially Cornell University, USA for providing me 6 months research opportunity.

\section{References}

1. Rascio N, Casadoro G, Ramina A \& Masia A (1985). Structural and biochemical aspects of peach fruit abscission (Prunus persica L. Batsch). Planta 164(1): 1-11.

2. Khalil SA, Ayub M, Zamir R, Sajid M, Muhammad A \& Faiq M (2012). Influence of postharvest hot water dip treatment on quality of peach fruit (Prunus persica L.). Journal of Medicinal Plants Research 6(1): 108113.

3. Zaman A, Ihsanullah I, Shah AA, Khattak TN, Gul S \& Muhammadzai IU (2013). Combined effect of gamma irradiation and hot water dipping on the selected 
nutrients and shelf life of peach. Journal of Radioanalytical and Nuclear Chemistry 298(3): 1665-1672.

4. Murray R, Lucangeli C, Polenta G \& Budde C (2007). Combined pre-storage heat treatment and controlled atmosphere storage reduced internal breakdown of 'Flavorcrest'peach. Postharvest biology and technology 44(2): 116-121.

5. Girardi CL, Corrent AR, Lucchetta L, Zanuzo MR, da Costa TS \& Brackmann A, et al. (2005). Effect of ethylene, intermittent warming and controlled atmosphere on postharvest quality and the occurrence of woolliness in peach (Prunus persica cv. Chiripá) during cold storage. Postharvest Biology and Technology 38(1): 25-33.

6. Wang L, Chen S, Kong W, Li S \& Archbold DD (2006). Salicylic acid pretreatment alleviates chilling injury and affects the antioxidant system and heat shock proteins of peaches during cold storage. Postharvest Biology and Technology 41(3): 244-251.

7.Gonzalez-Aguilar G, Tiznado-Hernandez M, Zavaleta-Gatica R \& MartınezTéllez M (2004). Methyl jasmonate treatments reduce chilling injury and activate the defense response of guava fruits. Biochemical and biophysical research communications 313(3): 694701.

8.Lurie S (1998). Postharvest heat treatments. Postharvest Biology and Technology 14(3): 257-269.

9. Han C, Zhao Y, Leonard S \& Traber M (2004). Edible coatings to improve storability and enhance nutritional value of fresh and frozen strawberries (Fragariax ananassa) and raspberries
(Rubus ideaus). Postharvest Biology and Technology 33(1): 67-78.

10. Jan I \& Rab A (2012). Influence of storage duration on physico-chemical changes in fruit of apple cultivars. $J$. Anim. Plant Sci 22(708714): 5.

11. Larmond E (1977). Laboratory methods for sensory evaluation of food: Research Branch, Canada Dept. of Agriculture.

12. Steel RG \& Torrie JH (1980). Analysis of covariance. Principles and procedures of statistics: A Biometrical Approach 401-437.

13. Ghafir SA, Gadalla SO, Murajei BN \& El-Nady MF (2009). Physiological and anatomical comparison between four different apple cultivars under coldstorage conditions. Afr J Plant Sci 3: 133-138.

14. Çandir EE, Temizyürek F \& Özdemir AE (2012). The effects of hot water dip treatments on the cold storage of Big Top nectarines. Journal of Applied Botany and Food Quality 82(2): 136140.

15. Ali S, Masud T, Abbasi KS, Ahmad A, Mahmood T \& Ali A (2014). Biochemical attributes of apricot as influenced by salicylic acid during ambient storage. International Journal of Biosciences (IJB) 4(10): 176-187.

16. Bhakshi P \& Masoodi F (2009). Effect of various storage conditions on chemical characteristics and processing of peach cv.'Flordasun'. Journal of Food Science and Technology (Mysore) 46(3): 271-274.

17. Kaur B \& Jawandha S (2013). Textural and biochemical changes in peach fruit during cold storage. Asian Journal of Horticulture 8(2): 556-560. 